encle om in 't gezagh van ons stadhouderschap in plaatse vanden schelmsen quimelaha Madiera te succederen, nevens zijn E. derwaerts gezonden onzen lieven getrouwen oom, den singadie van Maleije. ${ }^{1}$ ) Ende naar dien den dienst vande Compagnie wel lichtelijck zal requireren, dat den heere Admiraal haest uijt Amboina elders vertreckt, zoo hebben wij bij dezen op den heere Willem vanden Beeck, ${ }^{2}$ ) gedesigneert vervanger vanden meergemelten heere admiraal in het gouverno van Amboina, versocht, clat het zijn $\mathrm{E}$. gelieve naar het scheijden vanden heere de Vlamingh onze voorschreven last, in cas van substitutie, gehelijck op hem te nemen ende ons bij alle gelegentheden vande hoedanicheijt ende particuliere constitutie der landen punctuelijck t'advisercn, bevelende mijnen stadthouder, den singadje Maleije, jegenwoordich derwaerts gaende, ende andere mijne bevelhebbers in die landen geroerden heere vander Beeck met gelijcke eere ende dezelve macht als vanden heere Vlamingh geschreven aentenemen ende te gehoorzamen, alzoo wij alle 't zelve ten meesten dienste van onze croone ende manutentie van goede ordres inde landen opgemelt vinden te behoren.

Gegeven op Macquian, binnen onzen Huijze, $20^{\text {en }}$ April 1651.

\title{
CXCVII. AMBON.
}

\section{April 1651. $\left.{ }^{3}\right)$}

Op denzelfden dag (27 April 1651) dat de nieuwe gouverneur van Ambon, Willem van der Beeck, als zoodanig den eed aflegde, liet de superintendent De Vlamingh, ,alle Comp. ${ }^{s}$ onderdanen, zoo hier om ende bij het Casteel als langhs de Cust van Hitoe woonende", aan het Kasteel komen, om ,als Comp.s onderdanen den eet van getrouwicheijt ende speciale

1) Uit diens „Commissie” haal ik aan: „Des is oock mijne expresse wille, dat door gezeyde singadji in gewichtige zaacken niet sonder kennisse van aengemelte heeren (De Vlamingh en Van der Beeck) zal worden bestaen ofte aengevangen".

2) Deze (vgl. Corp. Dipl. I, bldz. 469, 471) was tot opvolger van De Vlamingh in het Ambonsche gouvernement benoemd in 1650 (Onuitgegeven Generale missive 10 December 1650). Zijne commissie dagteekent van $22 \mathrm{Dec}$. 1650, hij trad op 27 April 1651 (Onitgegeven, "Verbacl” van De Vlamingh).

3) Uit Overgekomen bricuen en papieren 000, 1652, III, fol. 219, v. - Ook bij Valentijn, Ambonsche zaaken, bldz. 172, v. 
gehoorzaemh $^{\mathrm{t}}$, aen $Z_{\mathrm{ijn}} \mathrm{E}$. te doen" (Onnitgegezen a'crbael van $D \mathcal{c}$ Vlamigh, waaruit ik onderstaand document overneem).

Eedt bij die van 't landt van Hitoe gedaan.

Gemerckt de trouweloose actitaten, bij den quimelaha Madiera ende zijnen aenhangh tegen $\mathrm{l}^{1} \mathrm{E}$ : Compagnie met het spolieren ende beroven harer goederen ende volckeren jonghst op verscheijde plaatsen gepleecht, ${ }^{1}$ ) verclaaren wij ondergeschreven, orangcaijen van het landt van Hitoe ende Ihamau, ${ }^{2}$ ) dat de gemelte Compagnie met goede redenen, als eenige van ons ende de hare door maechschappije den anderen zeer naer bestaende, behalven dat wij oock van een ende dezelve religie, te weten de Mahumetanise, zijn, een naarder opzicht op ons mach nemen encle ons dienvolgende op het nauwste als zij ommers konnen aen haar verlinden, gelijck als wij ons dienvolgende dan oock onder den diersten ede die wij cloen mogen, dat is op onze mousahapinij, op de hiervolgende articulen uijt onze eijgen vrijen wille aende voornoemde Compagnie naerder verbinden, als doen bij dezen.

Eerstelijck beloven ende sweeren wij, d'E: Compagnie gehouw ende getrouw te zullen zijn ende blijven,

ende dat wij dienvolgende oock met alle de gene, waar de voorschreven Compagnie nu reets mede in vrundtschap is ofte hiernaer noch vrundtschap zoude mogen comen te maacken, mede altoos als goede ende onze eijgen bezondere vrunden zullen omgaen, leven, handelen ende wandelen, zoo wijdt ende verre als ons dat bij voorschreven Compagnie zal werden g'accordeert ende toegelaten.

Gelijck wij dan oock daarentegen aende andere zijcle weder beloven ende sweeren, voor onze vijanden te achten, houden ende zullen houden alle de geene, waarmede d'E: Compagnie rechtevoort oorloch heeft ofte naarmaels noch zoude mogen crijgen, tot zoo lange dezelve oorloch dueren zal, zijnde specialijck daaronder gemeent ende begrepen den voorgemelten snooden quimelaha Madiera met alle die, welcke zijne zijde ende factien gunstich zijn ende dezelve volgen, egene van die gereserveert ofte uijtgezondert.

1) Zie hiervóór, bldz. 12.

2) Valentijn, Ambonsche Zaaken, bldz. 172, die dit stuk reeds heeft gepubliceerd, heeft dan ook in den aanhef: ,'t land Hitoe mitsgaders die van de Negryen Iha en Mahoe". Zooals steeds, heeft Valentijn de spelling hier en daar gewijzigd. 
Zoo beloven ende sweeren wij noch mede, met niemandt vanden quimelaha Madiera. encle zijne consorten ofte andere Compagnies vijanden cenige secrete correspondentien ofte t'samenspraacke te zullen houden, maar dat wij econtrarie alle de gene, die wij van voorschreven quimelaha aenhangh, zonder eenige onderscheijt van persoonen te maacken, hoe nae zij' ons oock in bloede ofte van aenheijlijckens wegen zouden mogen bestaan, in onze handen comen te grijpen, op hoedanigen wijze het selve oock zoude mogen wezen, zonder eenen ommezien tijds daarmede te tarderen, zullen brengen ende leveren aende naeste suppoorten varide Compagnië, van ons afgelegen.

Item oock dat wij ons t'allen tijclen gereet ende vaerdich zullen laten vinden, op de ontbiedinge vande Compagnie, den algemeijnen vijandt zoo te water als te lande naar ons uijtterste vermogen te vervolgen ende distrueren; van alle welcke poincten, hetzij in 't geheel ofte ten deele, indien wij blijven in gebreecken, verclaren ende belijden wij ons zelfs liberlijck te wezen meijn-eedige ende met goede redenen landt, goet ende bloet te hebben verbeurt, dat alle wij mids dezen dan oock daar onder submitteren encle als te pande stellen, hebbende wij te zamen ende ijder van ons in 't bijzonder tot becrachtige van zulcks onze handen, volgens onze vaders wijze in het sweeren gebruijckelijck, gelecht op cle mousahaphij; waerentegen hebben wij, Arnold de Vlamingh van Oudtshoorn, ordinaris Raadt van India, oudt gouverneur ende directeur van Amboina ende als nu voor admiraal, superintendent ende expres Commissaris herwaerts gezonden, ende Willem vander Beeck, extraordinaris Raadt ende regerent gouverneur ende directeur vande provintie voorschreven, in onze respective voorschreven qualiteijten, voor ofte van wegen de Generale Compagnie belooft ende geswooren, als doen bij dezen, het landt van Hitoe nevens alle de geene waermede de Compagnie hier rechtevoort in aliantie is, zoo lange als zij haar naerde voordezen beraamde articulen ende rredecontracten oprecht ende getrouwelijck blijven comporteren, allenthalven, 'zoo wel voor publicq als heijmelijck gewelt, met uijtterste vermogen te helpen ende assisteren.

Dat [wij] versurgen sullen, de contracten, voor dezen bij wijlen mijnen heere den Generaal Antonio van Diemen met die van deze landen aangaande het betalen der nagelen ende coopen van Compagnies cleden geraemt, ${ }^{1}$ ) aen onze zijde wel, oprecht ende getrouw werden onderhouden ende naargecomen.

1) Vgl. Corp. Dipl., I, bldz. 297, v.v.; 316, v.v. 
Ende specialijck beloven ende sweeren wij bij dezen, dat wij noijt trachten zullen, ymant van het Mahumetis gevoelen afteleijden, maar zullen die vande gantsche cust van Hitoe ende wie elders meer van dat gevoelen zijn, van ons daarin ongemolesteert werden gelaten. .

Zoo zullen wij oock niet gecloogen, eenige jonge lieden van het Moors gevoelen, zonder speciael consent van haare ouders ende vrunden, met eenige Christen dochters trouwen ende midsclien, gelijck als dat dan volgen moet, Christen werden, maar nemen wij aen ende beloven, d'ouders ofte momboirs ${ }^{1}$ ) van zoodanige onmondige kinderen daar van te laten weten ende indien zij daerinne niet willen consenteren, dezelve weder datelijck tot hen te stieren. Soo waerlijck moet ons Godt almachtich helpen.

Aldus gepasseert ende beswooren in het Casteel Victoria in Amboina dezen seven-en-twintichsten April $\mathrm{A}^{\circ}$ 1651. ${ }^{2}$ )

\section{AMBON.}

5 Mei 1651. ${ }^{3}$ )

„Volgens d'expresse ordre van haare $\mathrm{Ed}^{\mathrm{n}}$ in Batavia” heeft De Vlamingh den 5 Mei 1651 ,,aen alle vreemclelingen bij publicque edicte gepreadverteert, van naar dezen noijt weder hier inde landen te verschijnen" (Onuitgegeven „Verbael” van De Vlamingh, waaruit ik onderstaand stuk overneem).

Placcaet noopende de vaert der vreemdelingen naar Amboina.

Arnold de Vlamingh van Oudtshoorn, Ordinaris Raadt van India, out gouverneur ende directeur dezer provintie Amboina, midsgaders admirael encle superintendent, als oock expresse commissaris der emportante gouvernementen Molucos, Amboina ende Banda, van wegen d'Hoo: Mogende Fleeren Staten Generaal, Zijn Hooch ${ }^{t}$ Willem Frederick, bij der gratie Godes prince van Orangien, grave van Nassouw et ${ }^{\mathrm{rn}}$, onder 't beleijt vanden $\mathrm{Ed}^{\mathrm{n}} \mathrm{H}^{\mathrm{r}}$ Carel Reniersz, gouverneur generaal over gants Nederlands Indien, allen den geenen

1) Mombers : voogden.

2) Valentijn, t.a.p., heeft hier nog (bldz. 173) de onderteekeningen.

3) Uit Oiẹrgekonen bricven en papicren 000, 1652, III, fol. 245, v. 